\title{
Coming Up Short: Family Composition, Income, and Household Savings
}

\author{
Stacia West University of Tennessee \\ Mahasweta Banerjee University of Kansas \\ Barbara Phipps University of Kansas \\ Terri Friedline University of Kansas
}

ABSTRACT Objective: Existing research on savings and liquid-asset accumulation is largely quantitative and focuses on descriptions of how income inequality leads to the ability or inability to save. What has been left out of this body of research is an in-depth exploration of the role family composition may play in the way that households accumulate liquid assets. The purpose of this research is to understand how lower and higher income single- and two-parent families characterize reasons for saving, obstacles to saving, and strategies to save. Method: A diverse sample of 42 parents of kindergarteners were asked questions about household saving at 2 time points. Results: Compared to other family types, lower income single mothers report little savings and aspirations toward very short-term savings horizons as a result of persistent income shortfalls. Unlike two-parent households, lowerincome single mothers discussed their reasons for avoiding mainstream financial institutions and opting to use cash instead. Conclusions: To alleviate economic inequality and improve households' ability to withstand financial volatility, social work practice and policy should consider implementing interventions that are responsive to the unique experiences of poverty by family composition.

KEYWORDS: asset building, financial capability, emergency savings, feminization of poverty, single mothers

doi: $10.1086 / 693047$

W ith persistent wage stagnation among middle- and working-class families, many Americans struggle to make ends meet (Mishel, Gould, \& Biven, 2015). The unforgiving economic environment has introduced additional obstacles to household saving, and many families find it nearly impossible to set aside savings that could cover an unforeseen financial change or help build future wealth (FINRA Investor Education Foundation [FINRA], 2016). For example, $47 \%$ of American households indicated they would face some difficulty covering a $\$ 400$ emergency expense-a staggering figure considering that income and expen-

Journal of the Society for Social Work and Research, Volume 8, Number 3. 2334-2315/2017/0803-0002/\$10.00 (C) 2017 by the Society for Social Work and Research. All rights reserved. 
diture volatility is commonplace (Larrimore, Arthur-Bentil, Dodini, \& Thomas, 2015; Collins, 2015; Hannagan \& Morduch, 2015). When households do have emergency savings, they tend to report less material hardship after an unexpected financial change (Gjertson, 2016; Mills \& Amick, 2010). Without liquid assets to cushion this volatility, some households may turn to high risk forms of consumer borrowing, which may threaten future financial security (Chase, Gjertson, \& Collins, 2011; Levy \& Bianchi, 2013).

A growing body of research in the social sciences has shed light on how income inequality and different individual and community characteristics impact the ability to accumulate liquid assets (Corporation for Enterprise Development [CFED], 2016; Lusardi, Schneider, \& Tufano, 2011; West \& Friedline, 2016). From this, we understand that the problem of inadequate savings is most pronounced among those earning the lowest wages and those who contend with racism and sexism in the market economy (Larrimore et al., 2015; CFED, 2016). Yet, we know little about how these families cope. Relative to the quantitative research, little qualitative work has explored how intersections of identity impact households' reasons, barriers, and strategies to save (Halpern-Meekin, Edin, Tach, \& Sykes, 2015; Sherraden, McBride, \& Beverly, 2010).

This paper explores how 42 households of different income levels and family compositions in a Midwestern American city frame reasons for saving, negotiate complex barriers to saving, and employ strategies to overcome those barriers. Such research is valuable, as it provides contemporary, detailed narratives of savings behavior that not only to lends insight into how some vulnerable populations experience the struggle for economic security, but also may inform existing and future antipoverty policy.

\section{Literature Review}

\section{Reasons for Saving}

Setting aside a portion of income as savings is typically motivated by the desire to weather unforeseen changes in expenditures, in anticipation of income fluctuations, or to realize future financial security through asset accumulation (Collins, 2015; Sherraden, 1991). In lower income households, the hierarchy of savings theory and quantitative research suggests that savings can be motivated by the need to meet immediate and basic needs in an environment where income is unstable and the ability to draw on existing assets is limited (Acs, Loprest, \& Nichols, 2009; Mills \& Amick, 2010; Pew Charitable Trusts, 2015; Xiao \& Noring, 1994). Compared to White and two-parent families, this income volatility is most pronounced within Black families and those headed by a single mother (Hardy \& Ziliak, 2014). Yet, it is not clear from the existing research on lower income families' savings behaviors if the 
disproportionate experience of income volatility by racial or ethnic identity and family composition relates to different savings motives.

These motives for saving are important because they illustrate the different opportunities and potential futures available to families. Perhaps due to having higher and more consistent incomes, as well as benefitting from intergenerational wealth transfers, White families with higher education and income identify their reasons for saving as children's college funds, homeownership, or retirement (Devaney, Anong, \& Whirl, 2007; Xiao \& Noring, 1994; Larrimore et al., 2015; Shapiro, 2004). This research suggests that class and race privilege may influence different families' savings goals. Some research has suggested that single-person households, lower income households, and households headed by a woman or person of color identified savings goals as those to meet basic daily expenses (Xiao \& Noring, 1994). However, other research has suggested that female heads of households were more likely than male heads of households to move toward longer term savings goals like retirement (Devaney et al., 2007). Qualitative research suggests that both single-parent and two-parent families across the low- to moderate-income spectrum save for unexpected emergencies and moderate-term events such as family vacations or weddings. These households at the lower end of the income spectrum discuss longer term savings horizons-such as saving for retirement, homeownership, or a child's education - but are all too often unable to attain them due to income shortfalls (Halpern-Meekin et al., 2015; Sherraden et al., 2010). Overall, the existing research examining households' motivations to save for the future indicates that income may be related to shorter and longer term goals; however, the empirical evidence regarding how household composition may impact reasons for household saving is both nascent and contradictory.

\section{Impediments to Saving}

Income insufficiency and family composition. Higher income is consistently related to increased ability to set aside income for savings (FINRA, 2016; CFED, 2016; Larrimore et al., 2015; Morduch \& Schneider, 2015). A nontrivial portion of the U.S. population, nearly 15\%, was living below the federal poverty level in 2014 (DeNavas-Walt \& Proctor, 2015). For Black and Latino/a households and households headed by a single parent, the disproportionate experience of poverty leaves them unable to make ends meet, much less set aside savings. (Child Trends, 2014; DeNavasWalt \& Proctor, 2015; Gjertson, 2016; Halpern-Meekin et al., 2015; Sherraden et al., 2010). Although income has been directly related to the ability or inability to save, little empirical research has been conducted to examine how the financial stress and insecurity related to parenthood directly relates to household saving. Considering this gap in the literature, theoretical evidence may lend some insight.

Lower income households function in a persistent state of financial insecurity in which complex financial decisions are made in an environment of stress and un- 
certainty (Edin \& Shaefer, 2015; Halpern-Meekin et al., 2015). Putting away savings is difficult mental work, especially in the context of poverty, which demands continuous attention to rapidly changing resources (Mullainathan \& Thaler, 2000). One wrong financial decision made by a lower income household in this highly stressful environment can lead to dire financial consequences. On the other hand, adequately resourced households have fewer financial stressors in their everyday lives and also tend to have more financial and social resources at hand to smooth the impact of financial volatility (Bertrand, Mullainathan, \& Shafir, 2004). When it comes to surviving income insufficiency and volatility and saving for the future, single-parent households are at a substantial material disadvantage. These households' access to financial resources and products may also be related to the ability to build savings.

Financial inclusion. Moderate- and upper-income households use financial institutions to manage and accumulate wealth (Beverly \& Sherraden, 1999). Some families, particularly lower income and Black and Latino/a households, may not use mainstream financial institutions for reasons that include being prohibited from opening account due to credit history, fees associated with account ownership, language and cultural barriers, or minimum-balance requirements that are not realistic for households experiencing precarious financial circumstances (Federal Deposit Insurance Corporation [FDIC], 2014; Sherraden, 2013). Although just under $8 \%$ of the total U.S. population did not have a bank account in $2014,18 \%$ of single mothers, $20 \%$ of Black respondents, and $18 \%$ of Latino/a respondents were unbanked (FDIC, 2014). Racial and ethnic minorities and single mothers also represented the largest proportion of the population using alternative financial services in lieu of services provided by a formal financial institution (FDIC, 2014). Thus, there is descriptive and theoretical evidence of how financial inclusion may relate to saving; however, there is little evidence to indicate if and how family composition plays a role in the use of mainstream financial institutions.

\section{Strategies for Saving and Extending Resources}

Institutional mechanisms. A growing body of theory and research has suggested that households are able to save when provided with institutionalized mechanisms to do so. Individuals are motivated to save when institutionalized mechanisms, financial education, attractive rates of return, savings-related subsidies, and facilitation were provided (Beverly \& Sherraden, 1999). For example, in higher income families, asset accumulation may occur through employer-matched automated retirement contributions. These opportunities to capitalize on and build assets are built into white-collar professional jobs. In lower paying jobs, where an employer many not offer paycheck direct deposit, there are fewer institutionalized opportunities for engagement with a financial product that may help automate saving. 
When provided the opportunity to save through automation, lower income households exhibit greater saving frequency and savings amounts when compared with institutional factors rather than individual characteristics and behaviors, or social position (Grinstein-Weiss, Wagner, \& Ssewamala, 2006; Han, Grinstein-Weiss, \& Sherraden, 2009). These institutionalized norms guiding access to mechanisms to build assets within the current economic context have produced and maintained economic inequality.

Familial and social networks. Considering the financial instability faced by households of all classes - working class, households of color, and single mothers-some may engage in strategies to extend income and build savings more so than others. In times of financial instability, reliance on family and friends to help cover expenses or extend limited financial resources is commonplace. Stack (1974) first documented the ways in which lower income individuals, particularly single women, exchange material goods and barter to weather financial challenges. These familial and kinship networks are pivotal, as they may mean the difference between having transportation to work or the ability to put food on the table (Rank, 1994). Relationships used to extend resources are often reciprocal, reflecting not only the familial and social context of financial volatility, but also the fluid nature of extreme poverty (Edin \& Shaefer, 2015; Shinn, Knickman, \& Weitzman, 1991).

Taken together, the current research reveals a partial picture of how families are trying to make ends meet and save for the future. In terms of motivations to save, the literature suggests that lower income households and those headed by a single mother or parents of color tend to save up small amounts and spend that savings over a shorter time period. It is also clear that these families face greater likelihood of experiencing income volatility, but there is limited evidence to determine whether this is a savings motive and if or how it relates to family composition and income level. Counter to both theoretical and empirical evidence, one study suggested that female heads of household are more likely to realize longer term savings goals than male heads of household (Devaney et al., 2007).

Quantitative and qualitative evidence suggests that higher income, two-parent households save greater amounts than lower income, single-parent households. Yet, there is little qualitative research that moves beyond how single mothers make ends meet to reveal how they situate their experience as single parents in relation to their ability to save or get ahead financially. Further, both quantitative and theoretical evidence suggests that lower income households and those headed by a single mother are more likely than other households to be disengaged from mainstream financial institutions. Little is known about how lower income families or those headed by a single parent characterize their experience with banks or relate that experience to their ability or inability to set aside savings.

To gain insight into these current gaps in the knowledge base, this study is framed by the following research question: How do income level and family com- 
position relate to households' identified reasons for saving, barriers to saving, and strategies to save?

\section{Method}

The qualitative research reported in this article is part of a larger mixed-methods study designed to test the effects of receiving financial education and/or a savings account on children's financial and educational outcomes. The parents did not receive any intervention, except that the parents knew if their child had a savings account and/or were receiving financial education.

\section{Study Context}

In August and September 2014 in a medium-sized Midwestern city, researchers piloted the feasibility of a randomized experiment in kindergarten classrooms that was designed to test the effects of an intervention-receiving financial education and/or a savings account-on children's financial and educational outcomes. Although parents were not expected to deposit any money into their child's account, at the end of fall 2014 we found that there was very little family-sponsored activity in the children's savings accounts. Consequently, in April and May 2015 we decided to explore parents' financial capability based on the assumption that less financially capable parents might find it harder to teach their children to save and spend money wisely.

\section{Sample Selection}

Prior to recruitment and implementation, this pilot experiment received approval from university and school district institutional review boards. Using classroom rosters and school-district contact information, parents were contacted by phone and/or e-mail to gain their verbal consent for their child's participation in the pilot experiment. In total, signed consent was received for 80 kindergarten children out of the potential 179 across all nine classrooms in three elementary schools. After their initial recruitment, the parents of kindergarten children were invited to participate in an online survey and in-depth qualitative interviews. Parents were informed that they would be compensated for their time and travel for both waves of data collection. Out of 80 kindergarten children, 40 parents (half of the sample) agreed to participate, and 36 face-to-face interviews were completed in the fall of 2014. Follow-up interviews with 32 participants, which contained additional questions related to financial capability of the participants, were conducted in the spring of 2015 (see Appendix). Eleven participants who completed fall 2014 interviews declined to participate in the spring 2015 follow-up interviews. Three additional participants who did not complete fall 2014 interviews participated in the spring 2015 interviews. 
Interview Protocol, Topics, and Format

Prior to conducting the in-depth interviews, parents' verbal consent was requested to reaffirm their consent to participate. Parents were informed of question topics and that they could choose not to answer a question or to discontinue the recording or the interview at any time. Interviews were audio recorded and transcribed. Parents' and children's names were changed to protect their identities and ensure confidentiality. In-depth interviews lasted for approximately 45 minutes and were usually conducted with one parent, often the mother. The interview guide for the in-depth interview consisted of two broad questions with probes to explore topics related to parents' financial attitudes, behaviors, and experiences.

\section{Author Reflexivity}

Four researchers with higher education conducted the interviews. All of them were female, three were married, and one was a single parent. Two had social work backgrounds, and two had backgrounds in early childhood education. The researchers were ethnically diverse, with two being White Americans, one of whom was an experienced educator. The other two researchers were immigrants, one a woman of color. All researchers were interested in family financial well-being, although they focused on different aspects of financial well-being. The single-parent researcher was particularly interested in feminization of poverty, but the other three researchers were more concerned with children's financial well-being. These differences and intersectionalities played a role in interpreting the findings, particularly with the emphasis leaning toward employing the theoretical lens of the feminization of poverty. Interviewing several participants twice allowed the researchers to build rapport with the families, and such prolonged engagement enhanced the confirmability and credibility of the findings.

\section{Analysis}

The interviews were transcribed by an external transcription service and loaded into ATLAS.ti and NVivo qualitative software packages for analyses. Content analysis of data pertaining to the two main questions was conducted by four researchers, two of whom conducted the interviews with parents. Using deductive and inductive reasoning based on responses to the research questions, the first and fourth authors assigned codes (categories and subcategories) to the ways that parents described their reasons for saving (Question 1), and their impediments to saving and strategies for saving (Question 2). The second author repeated this process independently. As coding differences occurred among authors during the early stages of open coding, the first and second authors used an iterative process to determine how best to categorize specific quotes into codes based on frequency of mention, overall tone and content of the interview, and how the specific statement related to other coded statements. To further establish confirmability, all authors then en- 
gaged in an iterative process of collapsing the original codes into broader themes to guide the organization and presentation of findings. The process ended when all four researchers reached a consensus with the overall analysis plan (Padgett, 2017).

\section{Sample Characteristics}

There were 42 parent participants; among those, 18 (43\%) were single mothers, and 24 (57\%) were from two-parent families. Among the single mothers, 13 were lower income (annual income below $\$ 35,000$ ), and the remaining 5 were higher income (annual income above $\$ 35,001$ ). With regard to saving, 10 of the single mothers reported being able to save money, and 8 could not save. Among the 24 married parents, 19 were higher income; 15 of those could save money, and 4 parents could not save. Of the married parents, 5 were lower income parents; 4 could save, and one could not save money. It is worth noting that all 5 higher income single mothers reported being able to save. Fifteen (36\%) of the 42 participating parents were of racial/ethnic minority status. Among them, 6 were Black ( 3 single parents and 3 from two-parent households), 3 were Asian (all from two-parent households), 2 were Arab (one single parent and one from a two-parent household), 2 were American Indian (one single parent and one from a two-parent household), and 2 were Latina (one single parent and one from a two-parent household). Table 1 shows parents' pseudonyms classified by income, marital status, race/ethnicity, and ability to save (drawn from quantitative survey).

\section{Findings}

\section{Reasons for Saving}

Based on qualitative interviews, we learned that both single-parent and two-parent families saved or tried to save for various reasons. Examining their reasons for saving, we grouped them into three categories: short-term, intermediate, and longterm.

Short-term saving goals. There were two primary short-term reasons for saving: to meet emergency needs, and to spend on special events or experiences.

Saving for everyday emergencies. Both types of families saved for emergencies, but only lower income parents, mostly single mothers $(n=5)$, reported saving for everyday emergencies. Grace, a lower income White mother of four young children, with some college education, stated that it is important to save for emergencies. She shared that she had inherited some money when her father died, but she "had to get into that to be a mother and live." Grace, who is in her mid-20s, continued that as she is getting older she is learning to appreciate the value of money and saving:

"I've learned [to] plan for emergencies and things that you don't see coming because it happens all the time, and I actually had to go through it to realize. Still, to this day, I 
don't really have a savings, but we're working on it. You just have to have money first before that [savings] can happen."

Because Grace now has a part-time job and needs her car to get to work, she must avoid emergency car breakdowns. Similarly, Isabella, a White mother of four chil-

Table 1

Income, Marital Status, Race/Ethnicity, and Ability to Save $(\mathrm{N}=42)$

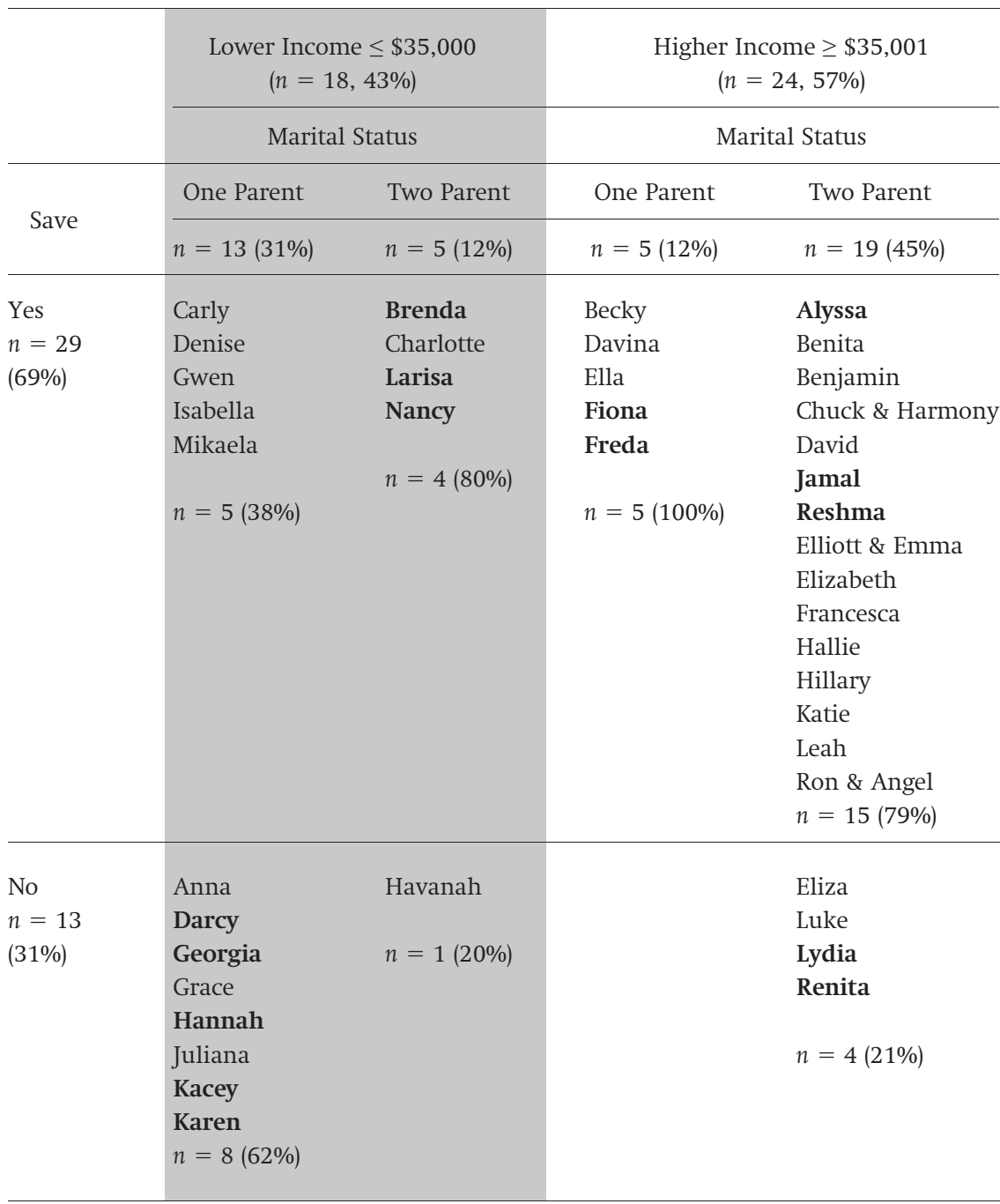

Note. Bold participant names indicate racial/ethnic minority status.

This content downloaded from 129.237.045.171 on October 04, 2018 09:50:55 AM

All use subject to University of Chicago Press Terms and Conditions (http://www.journals.uchicago.edu/t-and-c). 
dren, reported keeping a "20-dollar bill in my purse at all times. It is not to be spent on anything. That's emergency gas money." Mikaela, who had adopted her two grandsons, said, "We just get what we need. Save something if we still got some. Save just to save in case we need it."

On the other hand, higher income two-parent families referred to such savings in various ways, such as a "rainy day fund," "cushion fund," "safety net," or "emergency fund." However, amounts, methods, and what they are to be used for were quite different. Two-parent families generally reported saving larger sums to meet emergency needs, such as a washer or a refrigerator breaking down, home repairs, or a sick pet. In contrast, single mothers worried about car tires blowing out, car repairs, not being able to get to work, and being able to put food on the table. For example, Benita, who was not working at the time and was classified as a higher income mother due to her spousal income, said, "We try to keep both checking and saving account deposits high so if there is any emergency we would be able to cover it."

Saving for special events. Twelve families (29\%) mentioned saving for special occasions such as children's birthdays, Christmas presents, or special events such as Disney on Ice or a ballet performance. Another 4 families talked about saving for their recent weddings. Because 15 two-parent families were also higher income, they appeared more confident and casual than single mothers in discussing saving for special events. Nonetheless, Davina said she "starts saving for Christmas right after Christmas, and contribute towards it every month." On the other hand, Havanah, from a lower income two-parent household, reported that they saved to get married. "Our folks chipped in ... We've been married for 7 years but have not had a honeymoon. We're saving for a year, but the water heater broke. Now our goal is to have a honeymoon by our $10^{\text {th }}$ anniversary."

Intermediate saving goals. We classified intermediate goals as reasons for saving for expenses within 1 to 3 years, and there were two main such goals: planning a vacation, and buying big-ticket items for living.

Planning a vacation. About two thirds $(n=25,60 \%)$ of the families were saving for a vacation. However, two-parent higher income families' stories about vacation were different from lower income one- or two-parent families. Higher income two-parent families talked about going to Hawaii or Disneyland, while lower income parents could not afford such vacations. Larisa, a two-parent, lower income Latina mother stated that they were planning for a vacation "for the two of us instead of the whole family." She thought the entire family of three could go on a vacation in 2020. Similarly, Isabella, a single mother of four, said her children have told her stories of how their peers have traveled on airplanes, but she has never been able to take them anywhere.

Buying big-ticket items for living. About one third of both types of families $(n=14$, $33 \%$ ) talked about saving for big-ticket items, such as buying a new or bigger car, replacing an old refrigerator with a new one, buying new furniture, or upgrading 
or repairing their homes. For example, higher income, two-parent Francesca said, "We've saved, and we are getting a new fridge today. Next it will be the stove. Both're in their last legs." She was also saving for new furniture, but it seemed like "it's taking forever. We need a new living room set." In contrast, higher income single-mom Davina said she really wanted to buy a couch and found one, but she did not buy it. She preferred to save for an emergency, saying, "I have that cushion versus having a couch."

Long-term saving goals. When families were saving for something that they would spend on after 3 years or more, we categorized them as long-term saving goals. Such goals were related to home ownership in some form, such as buying a home (or a bigger or newer home), home repairs, or home remodeling. Two other such long-term goals were saving for children's education, and saving for retirement.

Home ownership. Almost half ( $n=19,45 \%$ ) of the families identified home ownership or something related to their home as the reason for saving. Unsurprisingly, 15 two-parent families and only 4 one-parent families mentioned home ownership as a goal. Two-parent, American Indian, lower income Brenda said she wanted to get a "bigger house and a better, nicer place that we all could fit in. But we can't do it right now . . . It'll be a long, long time for sure." Lower income single-mom Carly didn't "ever" see herself buying a house.

Children's education. About one-half $(n=22,52 \%)$ of the families were saving for or hoped to save for their children's college education. Although two-parent families in the higher income group were already saving a little for their children's education, one-parent lower income families only hoped to save for their children's education. However, two-parent families reported they could not pay for the entire education but wanted to give their children "as much of a chance as we can" "so they could leave college with as little debt or none if possible."

Retirement. About one-quarter ( $n=10,24 \%$ ) of the families mentioned saving for or hoping to save for their retirement. All were higher income two-parent families, except one mother from a two-parent lower income family.

\section{Impediments to Saving}

Most families identified barriers to saving. Eight lower income single mothers and one two-parent lower income mother-of those, 5 were women of color-could not save for the future. For example, Havanah, a two-parent lower income mother of a kindergarten child, struggled to save money due to the unstable low-wage, fulltime jobs both parents worked. Havanah tried "to save from both pockets, but the jar gets broken many times because things come up." She reported facing an emergency when her husband was in an accident and medical bills were an obstacle to paying rent; she successfully used crowdfunding to raise money to save the family from eviction. Although other families did not report facing such an imminent exigency, 
they identified several barriers to their saving, which were broadly grouped into four categories: insufficient income, unexpected expenses, lack of budgeting or over-spending, and parenting.

Insufficient income. Twenty-two (52\%) families identified insufficient income as a reason for inability to save. This was true for both types of families and in both income groups, but it was more pronounced among single-parent, lower income families of color. Among 3 higher income two-parent families, insufficient income was a barrier to their ability to meet wants, such as buying a special type of guitar. However, it was also true that 4 higher income married couples found it hard to save due to a combination of factors, including unstable income and larger family size, which appeared to be the most important factors. Three other two-parent families noted that moving from two incomes to one income had caused income inadequacy. Under such circumstances, not only were they unable to save, but they also at times had to borrow to meet unexpected expenses such as car repair "or something outside of basic food and living." However, one-parent families from both income groups expressed other reasons. Grace's remark is typical of such families: "I am not able to save now ... I always have to take care of the most important things first. When that's done, there's really not much there."

Unexpected expenses. Nine (21\%) families mentioned that unexpected expenses interceded their attempts at saving, and only 2 of these were one-parent families. Examples of unexpected expenses include house foundation repair (twice), a home not selling fast enough after a move, car breakdowns, unexpected pregnancies, and health issues. Renita, an Asian nonworking parent of one child, reported two health emergencies in the family that disrupted their savings: "His dad had a stroke, and we had to travel back and forth quite a bit to see him. That's gas money and food money." Also, such travel did not permit her husband to work full time or earn overtime pay, which "put us in a budget." And later, their child had surgery, but they were unaware that they would have to make a $\$ 500$ copayment prior to the surgery.

Lack of budgeting, overspending. A little more than one third ( $n=15,36 \%)$ of parents -12 two-parent families and 3 single-parent families - cited lack of budgeting and overspending as a reason for inability to save. The two-parent families' stories suggested tension between spouses regarding spending or saving/budgeting habits. Often, there was self-blame or other-blame, and sometimes there was conflict related to money matters. For example, Harmony blamed herself for overspending and lack of budgeting, saying "It was mostly tax return splurge" and "Mommy has a job now" that led to overspending. She concluded, "We're horrible about saving." Hallie blamed herself for her "horrible shopping addiction" and explained that her husband likes to "watch five dollars growing ... in a bank." Similarly, Alyssa, a twoparent Black mother, thought she was "not the best saver," but she also did not "have extravagant taste." She blamed her husband for "squirreling away on stuff pretty easily." 
Elizabeth shared that her husband was "into keeping up appearances," and although he was not a stable earner, he expected her to spend her money and she did so to make him happy. Single-parent Gwen said she was not good at tracking expenses and has been overspending, but she is more conscious about it now and is trying to watch "where I am spending my money."

Parenting. A little more than one third $(n=15,36 \%)$ of the parents stated that raising children is expensive in various ways. In some cases, one parent chose to stay at home to take care of the child-a double-edged sword because it is desirable to take care of one's own child, but it requires the family to have only one income. Other parents identified that either they needed a bigger or better house or a car since they had to raise children. Like other single mothers, Black single-parent Kacey identified paying for shoes and clothes for growing children as an expense that came in the way of saving. Five families (4 higher income, two-parent households) identified child care as expensive. Finally, 5 single-parent, divorced mothers reported that the regularity or amount of child support payments was often inadequate. Becky said, "It is significantly harder to have a child than it is to be without a kid. It has been a real eye-opening experience. Insurance, medical, you know, you're like, 'My god, it's so expensive. Everything is so expensive."

\section{Strategies for Saving}

These families discussed two different strategies for saving: thrift strategies to make ends meet, and strategies to extend resources.

Thrift strategies. Sixteen (42\%) families, primarily lower income single mothers $(n=10)$, identified ways to stretch income further. Thrift strategies used by these parents include eating at home instead of eating out, using secondhand goods, borrowing books and movies from the library instead of buying, and sharing housing with others to cut living expenses. Carly said she was "really strict about money." On the other hand, higher income, two-parent families $(n=10)$ mentioned comparison shopping, buying at sales, and postponing buying as their thrift strategies. Hallie said, "I'm a bargain shopper, I get good deals."

Income extension strategies. About a third $(n=11,26 \%)$ of both types of families bartered goods and services with family, friends, and neighbors to extend their resources. Examples of bartering include babysitting swaps, yard work, hair color, and massages. Single-parent Juliana said, "I think bartering is a great system." Also, a few families $(n=5,12 \%)$ thought if they could earn more income or manage their available income better they might be able save more. Francesca gave the example of saving money when there was income to offset the inevitable times when there would be no income due to her husband's nature of work. She said, "We're very feast or famine in our house." Single-parent Freda generated additional income by cooking and selling ethnic food to her readily available customers. 


\section{Mechanisms for Saving}

Many families identified various saving mechanisms they used alone or in combination. These include saving large or small amounts in banks, using bank direct deposits, mental accounting, using cash only, and reducing debt by paying it off or avoiding credit cards.

Saving larger or smaller amounts in banks. A little less than half $(n=19,45 \%)$ of the families mentioned that they save big or small amounts in banks. Seven two-parent families reported that they save large amounts from tax refunds in bank accounts for future use. Ella - a single-parent, higher income mother-said that because her income was inconsistent, whenever she earned a large amount she put it into a savings account to create reserve savings. Another 12 families (5 single-parent) reported saving smaller amounts in bank accounts. Although two-parent, higher income families mentioned saving anywhere from $\$ 400$ per month to setting aside an unspecified amount every two weeks, few lower income single parents stated they could set aside small amounts in banks as "otherwise it's free money," meaning it can be spent.

Using direct deposits in bank accounts. Seven families (17\%, only one single-parent) stated that they used direct deposit as a saving mechanism. Some mentioned having their pay directly deposited into bank accounts, with a certain proportion being diverted to a savings account, to children's college savings fund, or to a Roth IRA fund. Most of these parents appreciated the opportunity. As Alyssa, a married Black mother, stated, "I'm not necessarily going to do it myself."

Using cash only. On the other hand, lower income single parents ( $n=5,12 \%)$ tended to be unbanked and used cash only instead of a bank account. Denise, like some others, preferred cash because "you know how much is coming in and how much is going out." Grace and Carly preferred cash because they did not have bank accounts. Carly said, "It's just easier to manage the money. I won't get caught up in overdraft fees and things like that. I'd rather have it where I can control it."

Reducing debt. A little more than a third of the families $(n=15,36 \%)$ stated that reducing debt or avoiding credit cards (6 families, including 3 lower income singleparents) were mechanisms they used to enhance their savings. Eight families (one single-parent) aimed for paying off credit card debts by paying the full amount monthly. Two families (one single-parent) tried to pay off their student loans to eventually save, and 5 families ( 2 single-parent) reported paying off unspecified debts so they could "get our money to grow." Although paying off debt seemed more reasonable for two-parent higher income families, it was more of an aspiration for lower income single mothers. For example, Carly said, "I have a lot of debt. Most of it I have been able to pay back. There is a lot of stuff that I just don't pay anymore. I know that there is a lot of things that I owe and don't pay on." Those who avoided credit cards said things such as, "We have credit cards but we don't use them,"“My husband said he would 
take my card and stop me from spending," "I plan not to have any credit cards again," or "I don't have a credit card."

\section{Discussion}

The purpose of this research is to explore if and how family composition related to the ways that families frame reasons for saving, negotiate complex barriers to saving, and employ strategies to overcome those barriers. In some ways the results are consistent with the literature, suggesting that lower income households tend to save for shorter term horizons than higher income households (Xiao \& Noring, 1994), that insufficient income is a consistent barrier to saving in all lower income households (FINRA, 2016; Pew Charitable Trusts, 2015), and that lower income households tend to rely more on thrift and social networks than mainstream financial products to extend income (Edin \& Shaefer, 2015; FDIC, 2014). The findings, however, extend beyond existing quantitative literature to reveal the nuanced ways that family composition and income create differential savings motivations, barriers, and strategies. Specifically, we find that lower income single mothers' motivations to save, barriers to saving, and mechanisms to save are different than those of both higher and lower income two-parent families.

Lower income single mothers characterized short-term savings quite differently than higher income and two-parent families. For lower income single-mother households, short-term savings were intended to meet everyday household needs instead of to prepare for an unexpected financial emergency. This finding was unanticipated, as lower income households, those headed by a racial or ethnic minority, and those headed by a single mother are more likely to experience financial volatility (Hardy \& Ziliak, 2014). Yet, no single mother discussed losing a job or having a large unexpected medical bill as reasons to save, as did lower income twoparent families. Instead, their concepts of short-term reasons for saving were directly connected to their ability to make it to work or put food on the table for their children. Reasons for saving for single mothers included things like emergency gas money or having enough set aside to buy school clothes in August. For twoparent households, these short-term savings goals related to an unexpected expense like an appliance repair. This finding supports the hierarchy of savings theory (Xiao \& Noring, 1994) as well as evidence from qualitative work that suggests lowest income households and single-parent households identify "daily expenses" as motivations to save (Halpern-Meekin et al., 2015).

Attainment or aspiration to longer term savings goals was discussed by many types of households. Two-parent higher income households discussed longer term saving goals such as retirement or homeownership as probable or as a goal they were already working toward. The starkest difference in considering longer term savings goals was observed between lower income two-parent and single-parent 
families. Lower income two-parent families talked about buying a home as an aspiration for the future. Lower income single mothers either did not mention homeownership at all or indicated that they would never be in a financial position to buy a home. This finding was different from some qualitative work suggesting that both lower income single mothers and two-parent families identify homeownership as a savings goal (Halpern-Meekin et al., 2015). However, the study by Halpern-Meekin and colleagues (2015), which included lower income single mothers' discussions of homeownership, included women who were participating in homebuyer savings programs. Thus, it may be the case that women who participate in these programs are motivated to save for homeownership, whereas those who have not participated in such directed savings programs have not imagined homeownership as a realistic part of their future.

Second, although all families identified income as a barrier to saving, single mothers (more often than two-parent households) stressed that they simply did not have enough money to save because of the high costs of raising their children and the lack of child support. This is consistent with an abundance of literature documenting the feminization of poverty, whereby single mothers are at a persistent disadvantage in the market economy due to the competing demands of the workforce and the family. Without two wage-earning adults, these households are more likely to be in poverty and to struggle to set aside savings for the future (McLanahan \& Kelly, 2006).

Additionally, it was expected that lower income households, particularly those headed by a single parent, would report unexpected financial emergencies as impediments to their saving (Bertrand et al., 2004; Hardy \& Ziliak, 2014). These issues were commonly reported by two-parent and higher income families but not by lower income single mothers. This may have been because single mothers reported not being able to save at all; thus, an unexpected financial emergency would not have impacted savings behavior. Facing financial volatility without any savings as a cushion, these mothers may instead be turning to friends, family, or other financial products to make ends meet.

Finally, although all households discussed thrift and income-extension strategies to save, lower income single mothers comprised the majority of the sample that used cash for day-to-day financial transactions and did not mention direct deposit as a savings mechanism. This is consistent with the existing quantitative and theoretical literature regarding financial inclusion, where lower income families, single mothers, and racial and ethnic minority households tend to be unbanked or underbanked (Sherraden, 2013; FDIC, 2014). The ways in which institutionalized mechanisms for saving can create opportunities to accumulate assets were illustrated by the higher income and two-parent families. These households suggest that they would not be saving money toward their retirement or children's college accounts but for the automation of their accounts (Beverly \& Sherraden, 1999). 
These different experiences of using financial products by family composition may partially be due to access provided to financial products through work, as lower income single mothers are likely employed in service-sector occupations that are less likely to even offer direct deposit (Mullainathan \& Shafir, 2010; Povich, Roberts, \& Mather, 2014)

\section{Strengths and Limitations}

This research should be considered in light of several strengths and limitations. A strength, this paper allowed for exploration of how the findings relate to different household composition and income groups. Additionally, the study included interviews with a sizeable sample of parents that represent different races, ethnicities, and nationalities. Although this is a strength, the numbers within these groups were not large enough to make meaningful comparisons. Moreover, this research is limited by the interview protocol. As part of a larger study, only a small portion of the interview guide asked direct questions about savings behavior.

This research may inspire future studies that provide more in-depth analyses of these research questions with a similarly diverse sample. For example, how do identified savings goals translate to savings behaviors in the context of financial volatility? How are barriers to attaining savings goals similar and different based on family composition and racial or ethnic identity? And, which current practice or policy approach most effectively assists lower income families with building meaningful savings for the future?

\section{Implications}

Practice implications. The findings lead to several implications for social work practice and policy. First, lower income households should not be considered a monolithic client group, especially as it relates to mitigating financial volatility. Lower income single mothers differ from lower income two-parent households in terms of their savings goals, ability to save for the future, and use of financial products to realize their financial goals. Current matched savings programs that focus on moderate to longer term savings goals like homeownership, small business capitalization, and education may not resonate with lower income single mothers, as they lack sufficient income to make ends meet. More appropriate programs may include those that promote very short-term savings goals. These may include tax-time savings and prize-linked savings, as well as those programs that provide equitable access to banking and financial products (Cole, Iverson, \& Tufano, 2014; Grinstein-Weiss, Russell, Gale, Key, \& Ariely, 2016; Sherraden, 2013).

Building savings intended to cushion short-term financial changes may help households practice savings behaviors and engage with financial products that can be leveraged to actualize longer term savings goals. As the single mothers in this study discussed, using direct deposit as a savings mechanism was rare, and sav- 
ing small amounts in a bank account meant that the intended savings would be spent before having a chance to accumulate. However, nearly everyone expressed a sincere desire to set aside savings. In direct social work practice, introducing moderate-income and lower income clients to opportunities to improve financial capability-including incentivized and automated savings, debt reduction strategies, credit repair approaches, and others-might help them actualize financial goals. For some households, this may extend to increased use of financial products that can help build longer term assets. For others, income will continue to fall short of what is necessary to support a family and weather the occasional financial emergency. This suggests that policy approaches to improve financial stability must also address income insufficiency.

Policy implications. Asset-building approaches to poverty alleviation must respond to the systemic economic oppression experienced by women and racial and ethnic minorities that precludes these households from full and equitable participation in the market economy. For many working mothers, the possibility of earning an adequate wage to cover her family's basic expenses is out of reach. Thus, to approach social welfare policy with attention to the feminization of poverty necessitates substantial changes to the federal minimum wage and child-care subsidies. This may include introducing and advocating for living-wage policy, which would provide a decent wage for minimum-wage workers (Edin \& Shaefer, 2015; National Employment Law Project, 2016). Increased appropriations to the federal Child Care and Development Block Grant, which provides child-care subsidies for lower income households, may also help working single mothers maintain full-time, stable employment (Mills, Compton, \& Golden, 2011). These two policy changes could help increase income for moderate-income and lower income working families, in turn impacting their ability to cover necessary expenses and then set aside some savings.

As some of the respondents mentioned, they are able to save portions of their tax refund, likely due to the Earned Income Tax Credit (EITC). Their savings serves as a cushion in case of a financial emergency, or as a nest egg to jumpstart additional savings. To extend one of the most effective antipoverty policies in the U.S. (Marr, Huang, Sherman, \& DeBot, 2015), policy advocates and researchers recently introduced the federal Rainy Day EITC, which would provide households the opportunity to set aside a portion of their tax refund to be used later in the year. This deferred amount would be matched 2:1 (Edin, Greene, Halpern-Meekin, \& Levin, 2015). This policy approach reflects the realities of the lower income households in the study who identified shorter term savings goals as their priority.

\section{Conclusion}

Many households, especially those headed by single mothers, struggle to make ends meet and save for the future. The implications of not having savings to cover 
unexpected financial events or invest in the future are considerable. Some households risk their family's overall stability by failing to pay bills on time or going into debt. In recent years, a number of social work researchers have sought to uncover ways to help lower income families build financial assets and attain a more secure financial future. However, little research has explored how the composition of a family may impact reasons, obstacles, and strategies for saving, or what the implications of these similarities and differences may be for social work policy and practice.

This research suggests that lower income households headed by a single mother identify everyday expenses as savings goals, whereas two-parent families identify short-term emergencies as savings goals. Barriers to saving for lower income twoparent households include both income insufficiency and unexpected expenses, but lower income single mothers stress only insufficient income complicated by expenses of child care and lack of support from their children's fathers as barriers to saving. Few lower income single mothers in this study identified institutional mechanisms to save, such as direct deposit; instead, many relied on cash.

These different experiences have implications for social work policy and practice. For example, lower income single mothers may have better outcomes in a tax-time savings program that allows them to capitalize on a savings opportunity but does not penalize them for early withdrawal. Moderate-income two-parent families may find success saving for a down-payment on their first home through an individual development account. As social workers develop and implement programs to improve the financial stability of families, they should do so with a grounded understanding of the volatile and tense financial lives of many of their clients.

\section{Author Notes}

Stacia West, $\mathrm{PhD}$, is an assistant professor at the University of Tennessee.

Mahasweta Banerjee, PhD, is a professor at the University of Kansas.

Barbara Phipps, PhD, is an associate professor at the University of Kansas.

Terri Friedline, PhD, is an assistant professor at the University of Kansas.

Correspondence regarding this article should be directed to Stacia West, 193 Polk Ave. Ste. E,

Nashville, TN 37210 or via e-mail to swest11@utk.edu

\section{Acknowledgments}

The authors gratefully acknowledge funding of this research by the National Endowment for Financial Education.

\section{Appendix}

Quantitative Online Survey (used in fall 2014 and spring 2015)

1. What is your household's approximate annual income, including wages, tips, investment income, public assistance, income from retirement plans, etc.? Ranges from Less than $\$ 5,000$ to More than $\$ 75,000$, and a category I don't know 
2. Do you (or your spouse/partner) have any money saved? Think about money in accounts, investments, money at home, and money other people are holding for you. Answer choices: Yes, No, I don't know, Prefer not to say

3. About how much money do you (including your spouse/partner) have saved? Answer choices range from Between $\$ 1$ and $\$ 99$ to Over $\$ 2,000$

4. Where do you (or your spouse/partner) have savings? Please select all that apply

a. In a bank or credit union

b. With an investment company

c. In a pension plan

d. At home

e. Somewhere else, please specify

Qualitative Interview Guide (Question 1 in fall 2014; questions 1 and 2 in spring 2015)

1. Tell me about a recent time when you tried to set aside some money to savefor anything, it doesn't matter if it was a big or small amount. [If interviewee can recount a time],

a. What have you needed to give up in the immediate present to save for the future?

b. Can you tell me about a time you needed to postpone buying something so that you could save?

c. Typically, what are the reasons/goals for your saving?

d. Why are these goals important to you?

2. What do you consider to be barriers to your financial capability? By financial capability, we mean having adequate opportunity and ability to earn, save, borrow, invest, and protect your money.

a. What might enhance your financial capability?

\section{References}

Acs, G., Loprest, P., \& Nichols, A. (2009). Risk and recovery: Documenting the changing risks to family incomes. Retrieved from the Urban Institute website: http://www.urban.org/UploadedPDF 1411890_risk_and_recovery.pdf

Bertrand, M., Mullainathan, S., \& Shafir, E. (2004). A behavioral-economics view of poverty. American Economic Review, 94, 419-423. doi:10.1257/0002828041302019

Beverly, S. G., \& Sherraden, M. (1999). Institutional determinants of saving: Implications for low-income households and public policy. Journal of Socio-Economics, 28, 457-473. doi:10 .1016/S1053-5357(99)00046-3

Chase, S., Gjertson, L., \& Collins, J. (2011). Coming up with cash in a pinch: Emergency savings and its alternatives (Issue Brief No. 6). Madison, WI: Center for Financial Security, University of 
Wisconsin-Madison. Retrieved from https://static.newamerica.org/attachments/8422-much -ado-about-emergency-savings/Michael\%20Collins\%20Paper.f9bb1db94b8540b49e6726 195dbbb3d2.pdf

Child Trends. (2014). Percentage of children who are poor or low income, by race and Hispanic origin: 2014. Retrieved from http://www.childtrends.org/wp-content/uploads/2014/09/04_fig2.jpg

Cole, S., Iverson, B., \& Tufano, P. (2014). Can gambling increase savings? Empirical evidence on prizelinked savings accounts (White Paper No. 10). Oxford, UK: Saïd Business School. Retrieved from http://dx.doi.org/10.2139/ssrn.2441286

Collins, J. (Ed). (2015). A fragile balance: Emergency savings and liquid resources for low-income consumers. New York, NY: Springer.

Corporation for Enterprise Development (CFED). (2016). 2016 Assets and opportunity scorecard. Retrieved from http://assetsandopportunity.org/scorecard/about/main_findings/

DeNavas-Walt, C., \& Proctor, B. (2015). Income and poverty in the United States: 2014. Retrieved from the U.S. Census Bureau website: http://www.census.gov/hhes/www/poverty/

Devaney, S. A., Anong, S. T., \& Whirl, S. E. (2007). Household savings motives. Iournal of Consumer Affairs, 41, 174-186. doi:10.1111/j.1745-6606.2006.00073.x

Edin, K., Greene, S., Halpern-Meekin, S., \& Levin, E. (2015). The Rainy Day EITC. Retrieved from the Corporation for Enterprise Development website: http://cfed.org/assets/pdfs/The _Rainy_Day_EITC.pdf

Edin, K., \& Shaefer, L. (2015). \$2.00 a day: Living on almost nothing in America. Boston, MA: Houghton Mifflin Harcourt.

Federal Deposit Insurance Corporation (FDIC). (2014). 2013 FDIC national survey of unbanked and underbanked households. Retrieved from https://www.fdic.gov/householdsurvey/2014 _unbankedreport.pdf

FINRA Investor Education Foundation (FINRA). (2016). Financial capability in the United States 2016. Retrieved from http://www.usfinancialcapability.org/downloads/NFCS_2015_Report _Natl_Findings.pdf

Gjertson, L. (2016). Emergency saving and household hardship. Journal of Family and Economic Issues, 37(1), 1-17. doi:10.1007/s10834-014-9434-z

Grinstein-Weiss, M., Russell, B. D., Gale, W. G., Key, C., \& Ariely, D. (2016). Behavioral interventions to increase tax-time saving: Evidence from a national randomized trial. $\underline{\text { Oournal of }}$ Consumer Affairs, 51(1), 3-26. doi:10.1111/joca.12114

Grinstein-Weiss, M., Wagner, K., \& Ssewamala, F. M. (2006). Saving and asset accumulation among low-income families with children in IDAs. Children and Youth Services Review, 28, 193-211. doi:10.1016/j.childyouth.2005.03.005

Halpern-Meekin, S., Edin, K., Tach, L., \& Sykes, J. (2015). It's not like I'm poor: How working families make ends meet in a post-welfare world. Oakland, CA: University of California Press.

Han, C., Grinstein-Weiss, M., \& Sherraden, M. (2009). Assets beyond savings in individual development accounts. Social Service Review, 83(2), 221-244. doi:10.1086/600861

Hannagan, A., \& Morduch, J. (2015). Income gains and month-to-moth income volatility: Household evidence from the US Financial Diaries (Working Paper No. 1). Retrieved from U.S. Financial Diaries website: http://www.usfinancialdiaries.org/paper-1

Hardy, B., \& Ziliak, J. P. (2014). Decomposing trends in income volatility: The "wild ride" at the top and bottom. Economic Inquiry, 52, 459-476. doi:10.1111/ecin.12044

Larrimore, J., Arthur-Bentil, M., Dodini, S., \& Thomas, L. (2015). Report on the economic well-being of U.S. households in 2014. Retrieved from the Board of Governors of the Federal Reserve System website: https://www.federalreserve.gov/econresdata/2014-report-economic-well -being-us-households-201505.pdf 
Levy, R., \& Bianchi, N. (2013). Know your borrower-The four need cases of small-dollar credit consumers. Retrieved from the Center for Financial Services Innovation website: http:// cfsinnovation.org/research/know-your-borrower-the-four-need-cases-of-small-dollar -credit-consumers/

Lusardi, A., Schneider, D., \& Tufano, P. (2011). Financially fragile households: Evidence and implications (Working Paper No. 17072). Cambridge, MA: National Bureau of Economic Research. doi:10.3386/w17072

Marr, C., Huang, C., Sherman, A., \& DeBot, B. (2015). EITC and Child Tax Credit promote work, reduce poverty, and support children's development, research finds. Retrieved from the Center on Budget and Policy Priorities website: http://www.cbpp.org/sites/default/files/atoms /files/6-26-12tax.pdf

McLanahan, S. S., \& Kelly, E. L. (2006). The feminization of poverty. In J. Chafetz (Ed.), Handbook of the sociology of gender, (pp. 127-145). New York, NY: Springer.

Mills, G., \& Amick, J. (2010). Can savings help overcome income instability? Retrieved from the Urban Institute website: http://www.urban.org/research/publication/can-savings-help -overcome-income-instability

Mills, G., Compton, J., \& Golden, O. (2011). Assessing the evidence about work support benefits and low-income families. Retrieved from the Urban Institute website: http://www.urban.org /research/publication/assessing-evidence-about-work-support-benefits-and-low-income -families

Mishel, L., Gould, E., \& Biven, J. (2015). Wage stagnation in 9 charts. Retrieved from the Economic Policy Institute website: http://www.epi.org/publication/charting-wage-stagnation/

Morduch, J., \& Schneider, R. (2015). Emergency savings. Retrieved from the U.S. Financial Diaries website: http://www.usfinancialdiaries.org/issue4-emersav

Mullainathan, S., \& Shafir, E. (2010). Savings policy and decisionmaking in low-income households. Retrieved from the National Poverty Center website: http://nationalpovertycenter.net /publications/policy_briefs/brief24/policybrief24.pdf

Mullainathan, S., \& Thaler, R. (2000). Behavioral economics (Working Paper No. 7948). Retrieved from the National Bureau of Economic Research website: http://www.nber.org/papers /w7948

National Employment Law Project. (2016). It's time to raise the minimum wage (Fact Sheet). Retrieved from http://raisetheminimumwage.org/pages/fact-sheet-time-to-raise-the-minimum -wage

Padgett, D. (2017). Qualitative methods in social work research ( $3^{\text {rd }}$ ed). Los Angeles, CA: Sage Publications.

Pew Charitable Trusts. (2015). The role of emergency savings in family financial security: How do families cope with financial shocks? Retrieved from http://www.pewtrusts.org/ /media/assets/2015 /10/emergency-savings-report-1_artfinal.pdf?la = en

Povich, D., Roberts, B., \& Mather, M. (2014). Low-income working mothers and state policy: Investing for a better economic future (Policy Brief Winter 2013-2014). Retrieved from the Working Poor Families Project website: http://www.workingpoorfamilies.org/wp-content/uploads 12014/02/WPFP_Low-Income-Working-Mothers-Report_021214.pdf

Rank, M. (1994). Living on the edge: The realities of welfare in America. New York, NY: Columbia University Press.

Shapiro, T. M. (2004). The hidden cost of being African American: How wealth perpetuates inequality. New York, NY: Oxford University Press.

Sherraden, M. (1991). Assets and the poor: A new American welfare policy. Armonk, NY: ME Sharpe. 


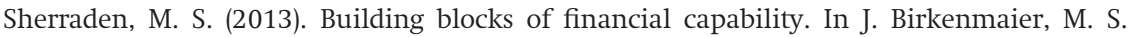
Sherraden, \& I. Curley (Eds.), Financial education and capability: Research, education, policy, and practice (pp. 3-43). New York, NY: Oxford University Press.

Sherraden, M. S., McBride, A. M., \& Beverly, S. (2010). Striving to save: Creating policies for financial security of low-income families. Ann Arbor, MI: University of Michigan Press.

Shinn, M., Knickman, J. R., \& Weitzman, B. C. (1991). Social relationships and vulnerability to becoming homeless among poor families. American Psychologist, 46, 1180-1187. doi:10 .1037/0003-066X.46.11.1180

Stack, C. B. (1974). All our kin. New York, NY: Basic Books.

West, S., \& Friedline, T. (2016). Coming of age on a shoestring budget: Associations between financial capability and financial behaviors of lower-income millennials. Social Work, 61 (4), 305-312. doi:10.1093/sw/sww057

Xiao, J. J., \& Noring, F. E. (1994). Perceived saving motives and hierarchical financial needs. Financial Counseling and Planning, 5, 25-44. Retrieved from the Association for Financial Counseling \& Planning Education website: http://www.afcpe.org/assets/journals/vol_52 .pdf

Manuscript submitted: August 30, 2016

First revision submitted: November 21, 2016

Second revision submitted: December 20, 2016

Accepted: December 22, 2016

Electronically published: July 19, 2017 